\title{
Iron cycling in Arctic methane seeps
}

\author{
Wei-Li Hong ${ }^{1,2} \cdot$ Pauline Latour $^{1,3} \cdot$ Simone Sauer ${ }^{1,3} \cdot$ Arunima Sen $^{4} \cdot$ William P. Gilhooly III $^{5} \cdot$ Aivo Lepland ${ }^{1,2}$. \\ Fotios Fouskas ${ }^{5}$
}

Received: 24 January 2020 / Accepted: 10 March 2020 / Published online: 26 March 2020

(C) The Author(s) 2020

\begin{abstract}
Anoxic marine sediments contribute a significant amount of dissolved iron $\left(\mathrm{Fe}^{2+}\right)$ to the ocean which is crucial for the global carbon cycle. Here, we investigate iron cycling in four Arctic cold seeps where sediments are anoxic and sulfidic due to the high rates of methane-fueled sulfate reduction. We estimated $\mathrm{Fe}^{2+}$ diffusive fluxes towards the oxic sediment layer to be in the range of 0.8 to $138.7 \mu \mathrm{mole} / \mathrm{m}^{2} /$ day and $\mathrm{Fe}^{2+}$ fluxes across the sediment-water interface to be in the range of 0.3 to $102.2 \mu \mathrm{mole} / \mathrm{m}^{2} /$ day. Such variable fluxes cannot be explained by $\mathrm{Fe}^{2+}$ production from organic matter-coupled dissimilatory reduction alone. We propose that the reduction of dissolved and complexed $\mathrm{Fe}^{3+}$ as well as the rapid formation of iron sulfide minerals are the most important reactions regulating the fluxes of $\mathrm{Fe}^{2+}$ in these cold seeps. By comparing seafloor visual observations with subsurface pore fluid composition, we demonstrate how the joint cycling of iron and sulfur determines the distribution of chemosynthesisbased biota.
\end{abstract}

\section{Introduction}

Iron is a critical micro-nutrient for marine phytoplankton and photosynthesis in the surface ocean (e.g., Boyd et al. 2000). As one of the most bio-available iron species, inorganic aqueous iron is supplied to the ocean by rivers, aeolian transport, glacial meltwater, icebergs, and hydrothermal vents and from anoxic marine sediments (Raiswell and

Electronic supplementary material The online version of this article (https://doi.org/10.1007/s00367-020-00649-5) contains supplementary material, which is available to authorized users.

Wei-Li Hong

wei-li.hong@ngu.no

1 CAGE- Centre for Arctic Gas Hydrate, Environment and Climate, The Arctic University of Norway in Tromsø (UiT), 9019 Tromsø, Norway

2 Geological Survey of Norway, 7040 Trondheim, Norway

3 European Institute for Marine Studies, Université de Bretagne Occidentale, 29280 Plouzané, France

4 Department of Biosciences and Aquaculture, Nord University, Bodø, Norway

5 Department of Earth Sciences, Indiana University-Purdue University Indianapolis, Indianapolis, IN 46202, USA
Canfield 2012; Tagliabue et al. 2017). In the absence of organic ligands, $\mathrm{Fe}(\mathrm{OH})_{3}{ }^{0}$ is the primary inorganic aqueous iron species at $\mathrm{pH} 8$ whereas $\mathrm{Fe}^{2+}$ dominates the aqueous iron pool under anoxic conditions (Raiswell and Canfield 2012). In anoxic marine sediments, $\mathrm{Fe}^{2+}$ is mostly produced through the reductive dissolution of iron (oxyhydr)oxide driven by the decomposition of particulate organic matter (POC) (or dissimilatory iron reduction (DIR), hereafter) (Lovley and Phillips 1988). The rates of $\mathrm{Fe}^{2+}$ production through this process depend on factors such as the quantity/type of organic matter, bottom seawater dissolved oxygen concentration (Lyons and Severmann 2006; Dale et al. 2015), the reactivity of different iron minerals (Raiswell and Canfield 1998; Larsen and Postma 2001), and solution pH (Straub et al. 2001). It has been well documented that large amounts of sulfide produced during sulfate reduction can effectively scavenge $\mathrm{Fe}^{2+}$ to form authigenic iron sulfide minerals, a process that has been commonly documented along global continental margins (Schulz et al. 1994; Reimers et al. 1996; Niewöhner et al. 1998; Riedinger et al. 2004; Raiswell and Anderson 2005; Riedinger et al. 2005; Lim et al. 2011; Fischer et al. 2012; Riedinger et al. 2017). The $\mathrm{Fe}^{2+}$ that is not consumed through the precipitation of iron sulfide minerals diffuses towards the oxic sediment layer where it is partially oxidized to form iron (oxyhydr)oxide precipitates. The small fraction of $\mathrm{Fe}^{2+}$ that eventually 
escapes the sediments can enhance the precipitation of ferrihydrite $\left(\mathrm{Fe}_{4} \mathrm{HO}_{8} \bullet 4 \mathrm{H}_{2} \mathrm{O}\right)$ in the bottom water and can be transported by bottom currents (Lyons and Severmann 2006; Raiswell and Canfield 2012; Lenstra et al. 2019). Seafloor macrofauna is known to either stimulate $\mathrm{Fe}^{2+}$ release to the bottom sediment or enhance $\mathrm{Fe}^{2+}$ consumption through oxidation in the surficial sediments, depending on the process involved. Bioturbation and bioirrigation increase the burial of labile organic matter and iron oxides which consequentially accelerates $\mathrm{Fe}^{2+}$ production through DIR (Canfield et al. 1993; Aller 1994). The active exchange between pore fluid and the overlying seawater as a result of faunal activities facilitates the escape of excess $\mathrm{Fe}^{2+}$ (Severmann et al. 2010). On the other hand, the introduction of oxygen into the sediment, as a result of pumping seawater by seafloor animals, also enhances the oxidation of $\mathrm{Fe}^{2+}$ and thus consumption (Aller 1980; Aller 1982).

Dale et al. (2015) have shown that $\mathrm{Fe}^{2+}$ fluxes from continental margin sediments were previously underestimated and more data are needed to refine global iron budgets. Cold seep sediments, where large quantities of methane fuel high rates of sulfate reduction, are an ideal environment to study the cycling of $\mathrm{Fe}^{2+}$ under persistent anoxic and sulfidic conditions, a case that resembles conditions of fast sulfate reduction due to high organic matter turnover rate along productive continental margins. The chemosynthesis-based macrofauna, whose survival depends on the release of reduced compounds from the cold seep sediments, may also play a significant role in determining the fate of $\mathrm{Fe}^{2+}$ in surficial sediments. Here, we investigate iron cycling from four Arctic methane seeps along the northern Norwegian margin in water depths ranging from 220 to $380 \mathrm{~m}$ (Fig. 1), where geochemical data are scarce to constrain the fate of iron in the sediments. We present porewater and sediment data to discuss the reactions and processes that affect $\mathrm{Fe}^{2+}$ cycling in shallow methane-rich anoxic sediments. In addition, we show how iron and sulfide fluxes impact the distribution of seafloor chemosynthesis-based biota, and vice versa.

\section{Study areas}

The investigated cold seeps are located along the glaciogenic northern Norwegian continental margin (Fig. 1). As one of the largest trough fans south of Svalbard (Lucchi et al. 2012), the major sediment types from Storfjordrenna are glacigenic diamictites and texturally heterogeneous marine sediments (Lucchi et al. 2012) as the result of repeated growth and retreat of grounding glaciers shaping the seafloor (Patton et al. 2015). The release of methane, shallow subsurface occurrence of gas hydrate, and chemosynthesis-based siboglinid frenulate polychaetes were documented from Storfjordrenna in recent papers (Hong et al. 2017; Sen et al. 2018a, b). Densely distributed craters and elevated methane concentrations (20$60 \mathrm{nM}$ ) in the bottom water have recently been reported from the Bjørnøyrenna area in the north central Barents Sea (Long et al. 1998; Andreassen et al. 2017), where ice sheets have carved the seafloor during the last glaciation and exposed the Middle Triassic bedrock (Long et al. 1998; Andreassen et al. 2017). Offshore of the Vesterålen Islands of northern Norway, the Hola trough is a cross-shelf feature with a width of $12 \mathrm{~km}$ and water depth around $200 \mathrm{~m}$ (Sauer et al. 2016). Active methane seepage was documented by recent geophysical (Chand et al. 2008) and geochemical investigations (Sauer et al. 2015, 2016). Ullsfjorden, a 70-km-long fjord in northern Norway, has a maximum water depth of ca. $285 \mathrm{~m}$ and numerous pockmarks that may be related to gas escape (Plassen and Vorren 2003; Sauer et al. 2016). The sediments in Ullsfjorden are composed of mostly glaciomarine trough fill (Plassen and Vorren 2003).

\section{Methods}

\section{Sampling and analyses}

The 13 sediment cores examined here were collected during three cruises from 2013 to 2016. Sediment cores were recovered by various techniques: box corer $(\mathrm{BC})$, multicorer (MC), and gravity corer (GC) as well as push corer (PC) and blade corer (BLC) using a remotely operated vehicle (ROV) onboard R/V Helmer Hanssen. The sediment cores from Storfjordrenna and Bjørnøyrenna were collected with the assistance of either a towed camera or a ROV (see Supplementary material for more information). Porewater was sampled by either $10-\mathrm{cm}$ or $5-\mathrm{cm} \mathrm{HCl}$-washed (ca. $10 \%$ ) rhizon samplers (Seeberg-Elverfeldt et al. 2005) with a pore size of $0.15 \mu \mathrm{m}$. Immediately after core recovery, MilliQ-rinsed rhizons were inserted through pre-drilled holes in the liners at $1-$ to $3-\mathrm{cm}$ intervals, depending on the core length and expected redox zones. Titration of total alkalinity (TA) with $\mathrm{HCl}(0.012 \mathrm{M})$ and analyses of dissolved $\mathrm{Fe}^{2+}$ spectrophotometrically with a ferrospectral complex as the color reagent (Traister and Schilt 1976) were performed onboard shortly after the pore fluids were collected. Samples for total sulfide ( $\Sigma \mathrm{HS}), \delta^{13} \mathrm{C}$ of dissolved inorganic carbon (DIC), cations, and anions were preserved onboard and analyzed on shore. For quantification of sulfide species in the sediments (i.e., acid-volatile sulfide (AVS) and chromium-reducible sulfide (CRS)) and their sulfur isotopic composition, chemical extraction of the sediments from cores S-904MC and S-1521GC was performed (Canfield et al. 1986; Fossing and Jørgensen 1989). Descriptions of the analytical protocols are provided in the Supplementary material. All pore fluid and solid-phase data are reported in 
Fig. 1 Locations of the four Arctic cold seeps and the corresponding sediment cores investigated. Cores with available sedimentary sulfur data and S/Al ratios from XRF core scanning were labeled in yellow. Site labels of cores with apparent changes in downcore sulfate concentrations were underlined

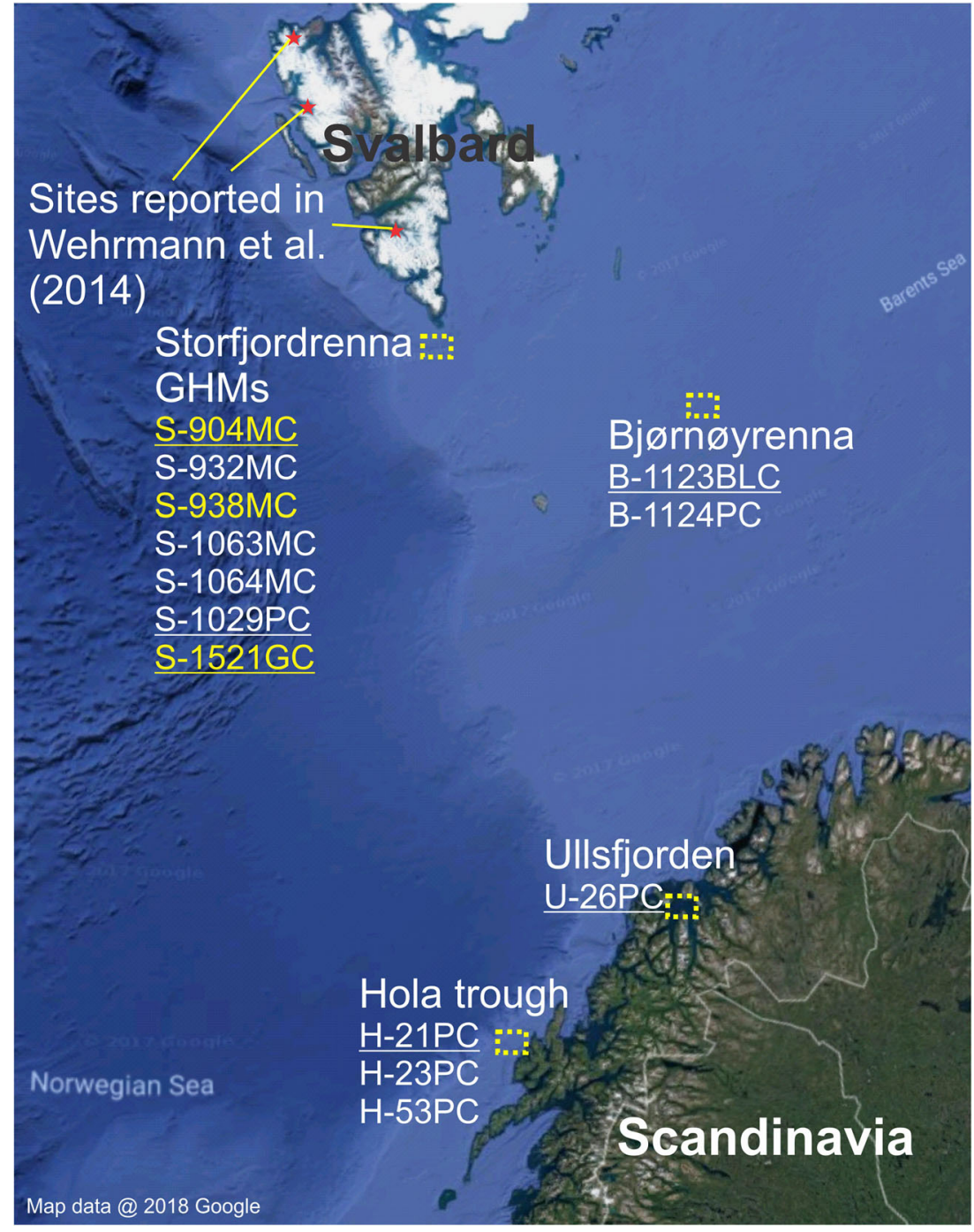

Tab. S1 and Tab. S2, respectively, of the Supplementary material.

\section{Flux and Gibbs free energy calculations}

The fluxes of $\mathrm{Fe}^{2+}$ towards the oxic sediment layer $\left(F_{\text {ox }}\right.$ hereafter) were determined by applying Fick's law:

$F_{\mathrm{OX}}=-\varphi \cdot D \cdot \frac{d \mathrm{C}}{d \mathrm{X}}$

where $\varphi$ is the porosity ( 0.7 ; Sen et al. 2018a), $D$ is the diffusion coefficient at the bottom water temperatures of the coring locations, and $\frac{d \mathrm{C}}{d \mathrm{X}}$ is the measured concentration gradient of $\mathrm{Fe}^{2+}$. For the diffusion coefficient of $\mathrm{Fe}^{2+}$, we considered both the molecular diffusion and bioturbation following

$D_{\mathrm{Fe}}^{\prime}=D_{\mathrm{Fe}}+D_{b}$

where $D_{\mathrm{Fe}}^{\prime}$ is the $D$ in Eq. (1) and $D_{\mathrm{Fe}}$ is the tortuosity- corrected molecular diffusion coefficient (which ranges from $1.98 \mathrm{E}-6$ to $2.01 \mathrm{E}-6 \mathrm{~cm}^{2} / \mathrm{s}$ ) at different bottom water temperatures, and $D_{b}$ is the coefficient for bioturbation assuming the process resembles diffusion (Boudreau 1997). We estimated $D_{b}$ with the empirical relationship by Middelburg et al. (1997).

To estimate the $\mathrm{Fe}^{2+}$ flux towards the sediment-water interface (i.e., $F_{\text {eff }}$ ), we used the equation proposed by Boudreau and Scott (1978):

$F_{\text {eff }}=\frac{\left(\varphi \cdot\left(D_{F e}^{\prime} \cdot \mathrm{kl}\right)^{0.5} \cdot \mathrm{C}_{\mathrm{Fe} . \mathrm{L}}\right)}{\left(\sinh \left[\left(\frac{\mathrm{kl}}{D_{F e}^{\prime}}\right)^{0.5} \cdot \mathrm{L}\right]\right)}$

where $C_{\mathrm{Fe} . \mathrm{L}}$ is the pore water concentration of $\mathrm{Fe}^{2+}$ at the bottom of the oxic layer in the sediments $\left(\mathrm{mole} / \mathrm{cm}^{3}\right)$, and $\mathrm{kl}$ is the first-order rate constant of $\mathrm{Fe}^{2+}$ oxidation (1/s), and $L$ is the thickness of the oxygenated layer in centimeters. 
Determining the values of $L$ and $C_{\mathrm{Fe} . \mathrm{L}}$ is challenging as we have no measurement for the dissolved $\mathrm{O}_{2}$ concentration in the pore fluid. We chose a value of $0.1 \mathrm{~cm}$ for $L$ based on the observed rapid reduction in nitrate concentration within the uppermost centimeter below the seafloor (Fig. 2) which indicates a likely thin oxic sediment layer. A similar oxygen penetration depth has been detected from in situ microprofiler measurements (Boetius and Wenzhofer 2013) at seep environments. Dale et al. (2015) assigned depths of oxygen penetration to be less than $0.1 \mathrm{~cm}$ for severely hypoxic to anoxic scenarios. We assume these environments have similar redox conditions as our study areas based on the high methane-
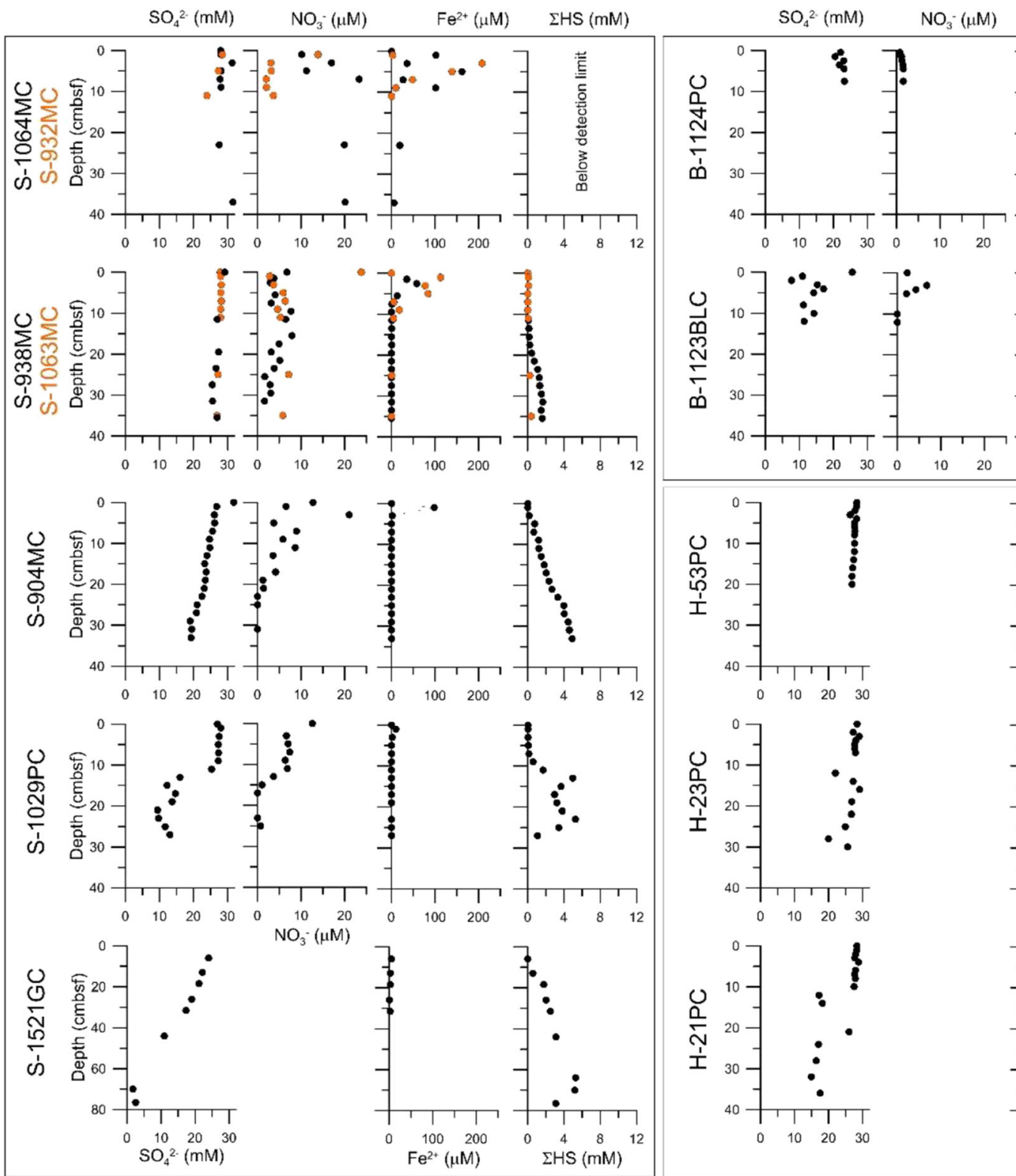

$\mathrm{Fe}^{2+}(\mu \mathrm{M}) \quad \Sigma \mathrm{HS}(\mathrm{mM})$
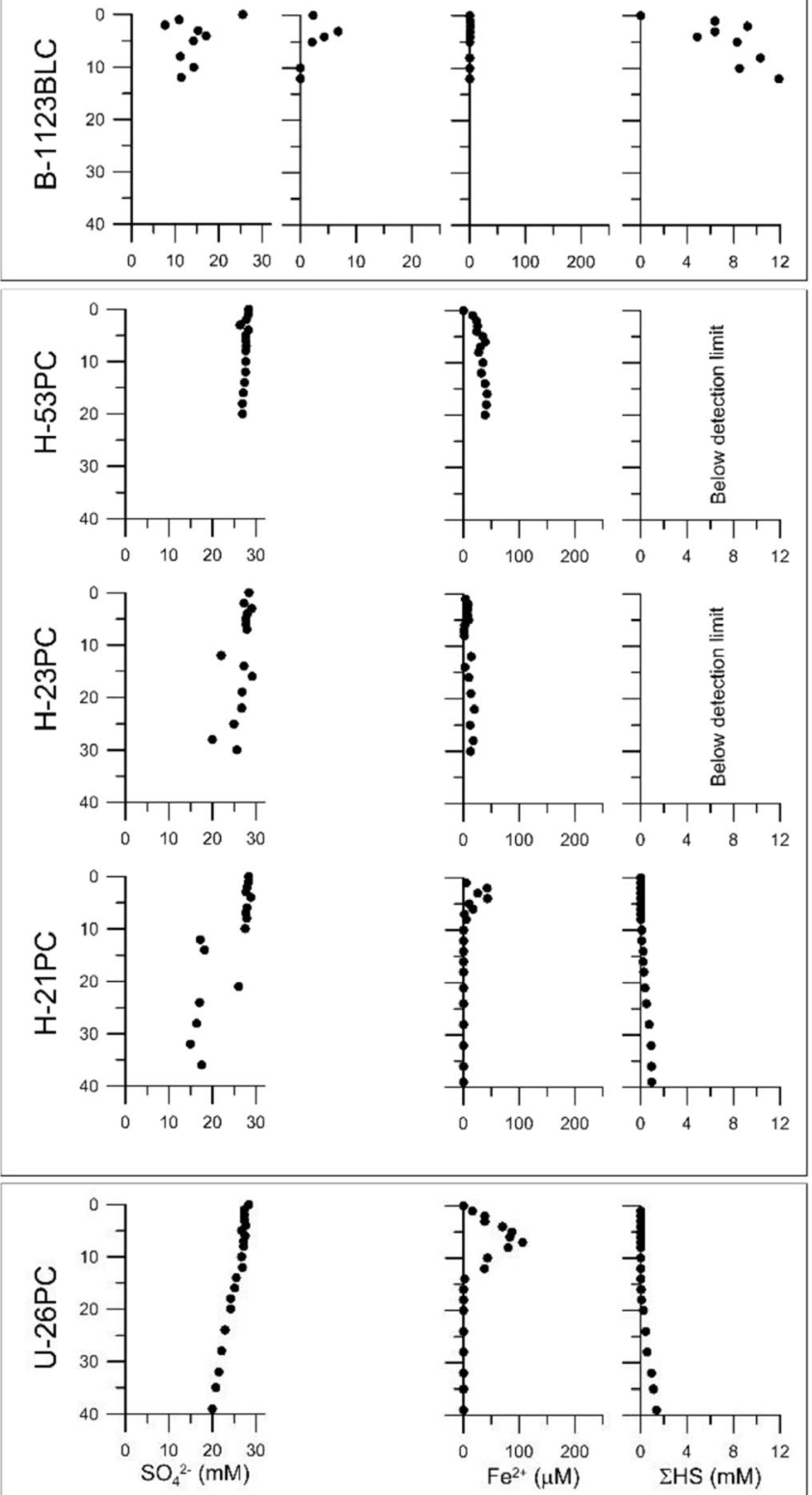

Fig. 2 Pore fluid data from the 13 investigated cores. Cores with similar pore fluid profiles were plotted together. Notice the different depth scale for S-1521GC 
fueled sulfate reduction rate. For the values of $C_{\mathrm{Fe} . \mathrm{L}}$, we estimated the $\mathrm{Fe}^{2+}$ concentration at $0.1 \mathrm{cmbsf}$ by interpolating the measured concentrations from 0 and $1 \mathrm{cmbsf}$. The resulting concentrations varied from 0.03 to $11.25 \mu \mathrm{M}$. The highest $\mathrm{C}_{\mathrm{Fe} . \mathrm{L}}$ appears at S-1063MC and S-1064MC .

The $k l$ value was calculated following Millero et al. (1987):

$$
\begin{aligned}
& k l=k\left[\mathrm{O}_{2}\right]\left[\mathrm{OH}^{-}\right]^{2} \\
& \log k=21.56-\frac{1545}{\mathrm{~T}}-3.29 \mathrm{I}^{0,5}+1.52 \mathrm{I}
\end{aligned}
$$

where $k$ is the rate constant describing the overall hydrolysis equilibria of reduced iron species (Millero et al. 1987), $I$ is the ionic strength for which we used the value 0.686 as calculated with the bottom seawater concentrations, and $T$ is the temperature for bottom water at each site. We adopted the $\mathrm{O}_{2}$ concentration of $320 \mu \mathrm{M}$ based on the values reported by Anderson et al. (1988). By assuming a $\mathrm{pH}$ of 8.1 (Ofstad et al. 2020) and $\mathrm{p} K_{w}$ values at the corresponding bottom water temperature at our sites (Millero 2001), we can derive $\left[\mathrm{OH}^{-}\right]$in the equation. The calculated fluxes and the parameters required for the calculation are reported in Tab. S3 in the Supplementary material. Similar calculations were done previously for the sediments from Svalbard fjords (Wehrmann et al. 2014). The fluxes obtained from Svalbard fjords are compared with the fluxes derived from our studied sites.

We also calculated molar Gibbs free energy $\left(\Delta G_{r}^{0}\right)$ with measured pore fluid compositions to determine whether a set of reactions is thermodynamically plausible. Detailed descriptions for these calculations can be found in the Supplementary material. The downcore $\Delta G_{r}$ changes are shown in Fig. S2 and reported in Tab. S6.

\section{Results}

\section{Porewater geochemistry}

Variable downcore sulfate gradients were observed from the 13 investigated cores (Fig. 2). Seven of the cores have almost constant sulfate downcore concentrations (S-1064MC, S-1063MC, S938MC, S-932MC, B-1124PC, $\mathrm{H}-53 \mathrm{PC}$, and $\mathrm{H}-23 \mathrm{PC})$. Distinct peaks in $\mathrm{Fe}^{2+}$ concentrations were observed from the top $10-15 \mathrm{~cm}$ of cores S-1064MC, S-1063MC, S-932MC, S-938MC, and B$1124 \mathrm{PC}$ with the highest concentrations ranging from 58 to $208 \mu \mathrm{M}$. For cores $\mathrm{H}-53 \mathrm{PC}$ and $\mathrm{H}-23 \mathrm{PC}, \mathrm{Fe}^{2+}$ was detected throughout the sediment columns with concentrations ranging from 10 to $40 \mu \mathrm{M}$. The concentrations of dissolved $\Sigma$ HS were low $(<20 \mu \mathrm{M})$ in these cores.

Compared with the cores with nearly constant downcore sulfate concentration, more apparent decreases in sulfate concentrations can be observed from cores S-904MC, S-1029PC, B-1123BLC, H-21PC, and $\mathrm{U}-26 \mathrm{PC}$. The reduction of sulfate coupled to anaerobic oxidation of methane is mostly responsible for the decreasing sulfate in these cores as suggested by the elevated TA and low $\delta^{13} \mathrm{C}$ values of dissolved inorganic carbon (Fig. S1 from Supplementary material). Distinct increases in $\mathrm{Fe}^{2+}$ with the highest concentrations ranging from 40 to $100 \mu \mathrm{M}$ were observed in the top $5-10 \mathrm{~cm}$ of these cores. Within the depth ranges where $\mathrm{Fe}^{2+}$ is detected, $\Sigma \mathrm{HS}$ is usually below the detection limit $(\sim 20 \mu \mathrm{M})$ or barely measurable. Greater amounts of $\Sigma H S$ are detected only below the depths where $\mathrm{Fe}^{2+}$ can no longer be detected. Gravity core S-1521GC has a similar sulfate concentration gradient as $\mathrm{S}-904 \mathrm{MC}$. The low sampling resolution for the top $40 \mathrm{~cm}$ of sediments however prohibits us from documenting the pore fluid profiles in detail. Cores $\mathrm{S}$ 1029PC and B-1123BLC show sudden declines in sulfate concentration within intervals of a few centimeters. Less than $10 \mu \mathrm{M}$ of $\mathrm{Fe}^{2+}$ can be detected in the top centimeters of these two cores with $\Sigma H S$ concentrations as high as $12 \mathrm{mM}$.

We also report the concentrations of pore fluid nitrate from the Storfjordrenna and Bjørnøyrenna cores (Fig. 2). In general, up to $20 \mu \mathrm{M}$ of nitrate can be detected from the depths where abundant $\mathrm{Fe}^{2+}$ is detected. The measured high nitrate concentration cannot be explained by contamination of nitric acid during the cleaning of rhizons and sample vials. We used only hydrochloric acid during our cleaning procedure. Also, the sample vials for nutrient samples were not acid washed before use. Complete consumption of nitrate is only observed within the deeper sediments of cores S-904MC, S-1029PC, and B-1123BLC where greater than $4 \mathrm{mM}$ of $\Sigma \mathrm{HS}$ is detected (Fig. 2).

\section{Iron flux calculation}

We estimated $F_{\text {ox }}$ ranging from 0.8 to $138.7 \mu \mathrm{mol} / \mathrm{m}^{2} /$ day and $F_{\text {eff }}$ varying from 0.3 to $102.2 \mu \mathrm{mol} / \mathrm{m}^{2} /$ day (Fig. 3 and Tab. S3). In general, high $F_{\text {eff }}$ corresponds to high $F_{\text {ox }}$ (Fig. 3). The fractions of $\mathrm{Fe}^{2+}$ escaping from the sediment columns, as defined by the ratios between $F_{\text {eff }}$ and $F_{\text {ox }}$ ( $R$ in Fig. 3), are higher at our sites compared with those from Svalbard fjords (Fig. 3), despite the generally lower concentrations of $\mathrm{Fe}^{2+}$ detected in our cores.

\section{Sediment sulfide speciation}

AVS includes different nano-particles of iron monosulfides, such as mackinawite and greigite, and even a small fraction of pyrite (Rickard and Luther 2007). CRS, on the other hand, has been shown to be composed of mostly pyrite (Canfield et al. 1986). Our data show variable amounts of CRS and AVS 

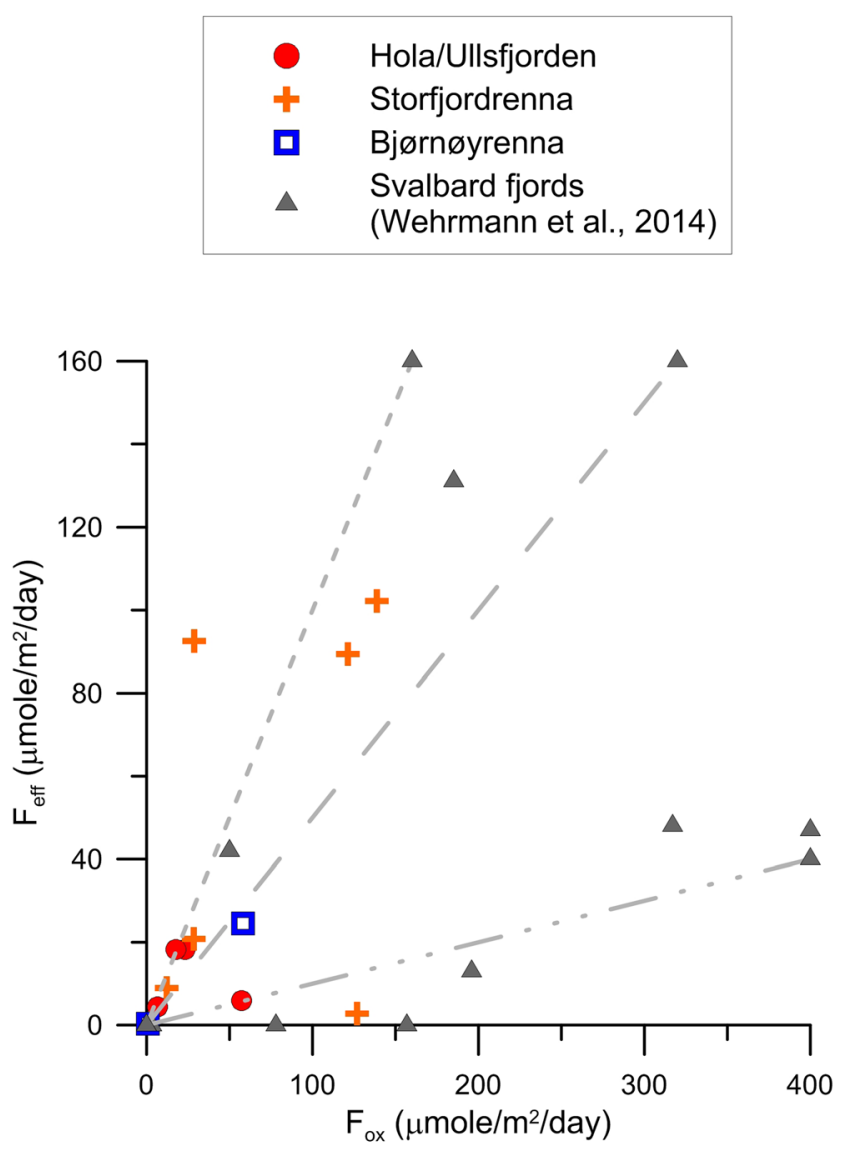

Fig. $3 \mathrm{Fe}^{2+}$ fluxes towards the oxic sediment layer $\left(F_{\text {ox }}\right)$ and efflux $\left(F_{\text {eff }}\right)$. The ratios between $F_{\text {eff }}$ and $F_{\text {ox }}(R)$ represent the fraction of $\mathrm{Fe}^{2+}$ escaping from the sediment columns. In general, we observed both higher $F_{\text {eff }}$ and $R$ from the investigated areas as compared with Svalbard fjords (Wehrmann et al. 2014), despite the lower $\mathrm{Fe}^{2+}$ concentrations detected in our pore fluid

in the sediments from cores S-904MC and S-1521GC (Fig. 4). CRS abundance increases abruptly from ca. $175 \mu \mathrm{mol} \mathrm{S} / \mathrm{g}$ ( $\mu$ mole sulfur in gram of dry sediment) in the uppermost sediments to more than $1500 \mu \mathrm{mol} \mathrm{S} / g$ at greater depths in both cores. The increase of CRS in core S-904MC corresponds to the depth where high $\mathrm{Fe}^{2+}$ concentrations were detected (Fig. 4). Abundant AVS (up to $154 \mu \mathrm{mol} \mathrm{S} / \mathrm{g}$ ) was detected in the first $30 \mathrm{~cm}$ of core S-1521GC. AVS is barely detectable at sediment depths approximately below $30 \mathrm{cmbsf}$ at S-1521GC.

The $8^{34}$ S-CRS values from S-904MC are the lowest ($15.3 \%$ V-CDT) in the uppermost $6 \mathrm{~cm}$ of sediments, gradually increase to ca. $-7 \%$ at $15-20 \mathrm{cmbsf}$ and slightly decrease to $-9.1 \%$ at the bottom of the core. The $\delta^{34} \mathrm{~S}$-CRS values from S-1521GC show a general increase with depth as well but exhibit several large fluctuations ranging between -24.3 and $7.4 \%$. These fluctuations in $8^{34} \mathrm{~S}-\mathrm{CRS}$ from S-1521GC do not correspond with the changes in CRS abundance. $\delta^{34} \mathrm{~S}$ AVS increases steadily with depth from -28.4 to ca. $22.1 \%$ at $65 \mathrm{cmbsf}$. Such an increase in $\delta^{34} \mathrm{~S}$-AVS values coincides with the increase in pore fluid $\mathrm{SHS}$ concentration. The $\delta^{34} \mathrm{~S}$-AVS values however do not correlate with AVS abundance at S-1521GC.

\section{Discussion}

We focus on the following reactions/processes that contribute to the cycling of iron in the sediments of the investigated cold seeps: (1) the release of $\mathrm{Fe}^{2+}$ from DIR, (2) the release of $\mathrm{Fe}^{2+}$ from other reactions such as the reduction of dissolved $\mathrm{Fe}^{3+}$, (3) precipitation of iron sulfide minerals, and (4) oxidation of $\mathrm{Fe}^{2+}$ in the sediments as a result of biological disturbance. We show that $\mathrm{Fe}^{3+}$ reduction and iron sulfide precipitation are likely the most important reactions governing the fate of $\mathrm{Fe}^{2+}$ at the investigated sites. There are other possible reactions, such as oxidation of $\mathrm{Fe}^{2+}$ by nitrate and oxygen as well as the precipitation of vivianite and incorporation of $\mathrm{Fe}^{2+}$ into carbonates that can also contribute to the consumption of $\mathrm{Fe}^{2+}$ in pore fluid (Egger et al. 2016). The pore fluid profiles however suggest only minor contributions of these reactions. We will thus not discuss these reactions in detail.

\section{Production of $\mathrm{Fe}^{2+}$ in the Arctic cold seep sediments}

Glacial erosion of iron-rich terrestrial rocks around Svalbard supplies iron (oxyhydr)oxide to marine sediments. Release of $\mathrm{Fe}^{2+}$ to the pore fluid through DIR explains the high $\mathrm{Fe}^{2+}$ concentrations observed in Svalbard fjord sediments (Wehrmann et al. 2014). The similar maximum concentrations of ammonium and phosphate (varying by factors of two and four, respectively) detected from the 11 cores at our three investigated areas (except for U-26PC and S-1521GC; Fig. S1 from the Supplementary material) suggest comparable rates of POC turnover and DIR, which, however, cannot explain the variable iron fluxes that could be two orders of magnitude different (Fig. 3). Different sets of reactions are required to explain the calculated wide range of $F_{\text {ox }}$.

The observation of high $\mathrm{Fe}^{2+}$ concentrations within the intervals where nitrate is still detectable from Storfjordrenna and Bjørnøyrenna (Fig. 2) points to a $\mathrm{Fe}^{2+}$ producing reaction that is thermodynamically more favorable than nitrate reduction. Following the classic early diagenesis sequence (Froelich et al. 1979), high $\mathrm{Fe}^{2+}$ concentrations can only be detected at depths where nitrate is completely reduced if $\mathrm{Fe}^{2+}$ is primarily supplied by DIR (c.f., Canfield et al. 1993). As a result, we suspect that a significant fraction of the $\mathrm{Fe}^{2+}$ observed in our pore fluids is produced by the reduction of dissolved and complexed $\mathrm{Fe}^{3+}$ (e.g., $\mathrm{Fe}(\mathrm{OH})_{4}{ }^{-}$and $\mathrm{Fe}(\mathrm{OH})_{2}{ }^{+}$) in the oxic and suboxic sediments. Reduction of complexed $\mathrm{Fe}^{3+}$ is energetically similar to oxic POC degradation and nitrate 
Fig. 4 Concentrations of sulfate, $\mathrm{Fe}^{2+}$, and $\mathrm{LHS}$ and the amounts of CRS and AVS as well as their corresponding $\delta^{34} \mathrm{~S}$ values from the two selected cores from Storfjordrenna
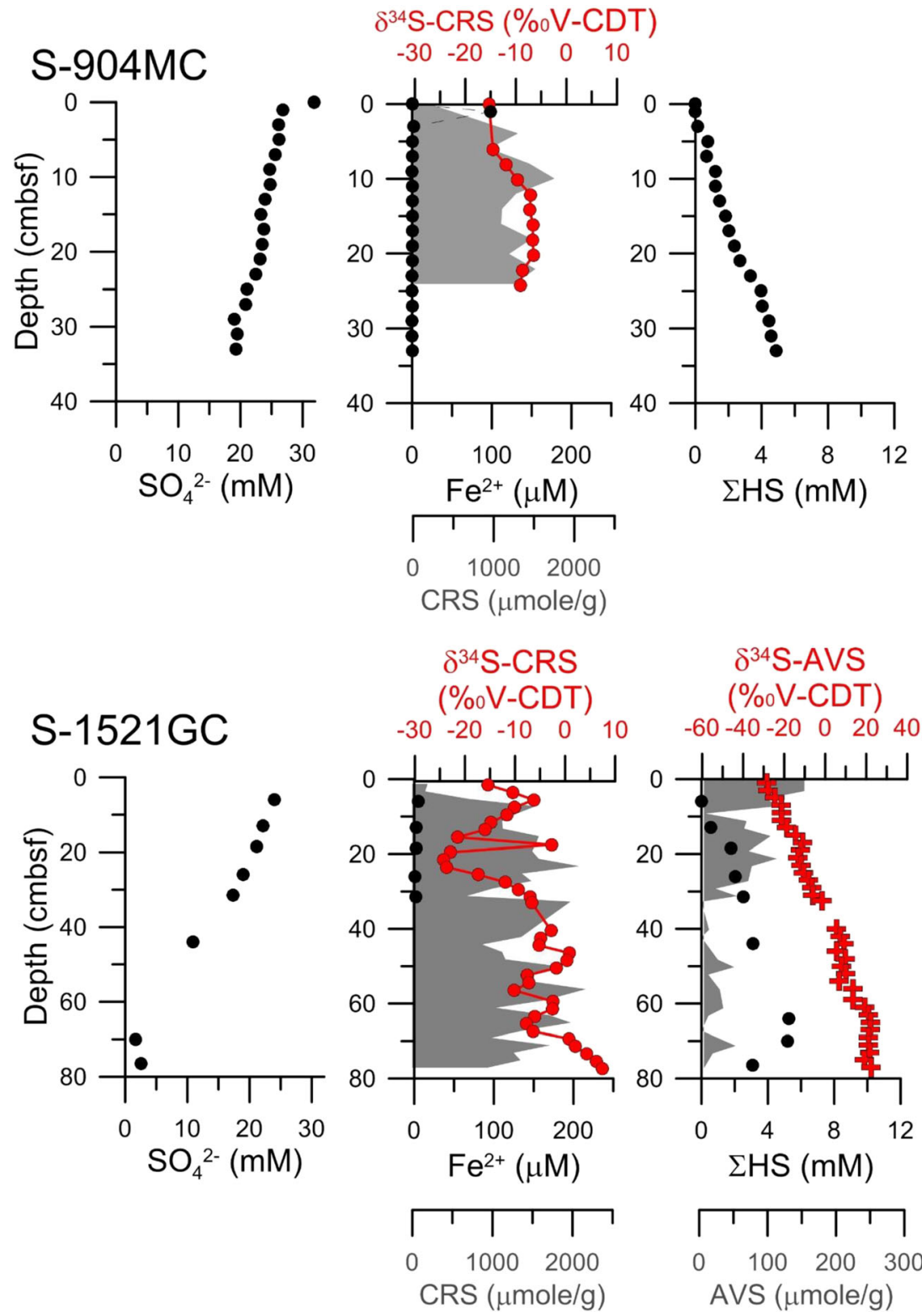

$\delta^{34} \mathrm{~S}-\mathrm{AVS}$

(\%०V-CDT) $-60-40-20 \quad 0 \quad 2040$

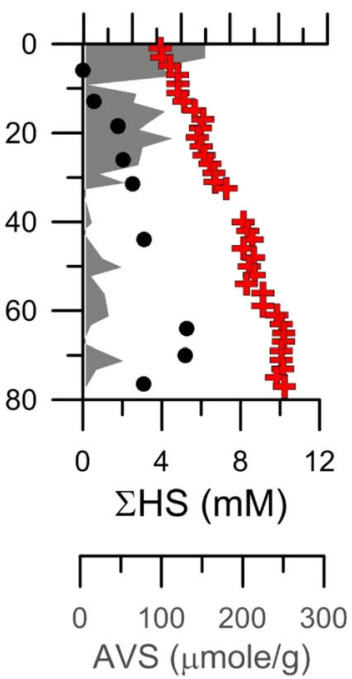

reduction based on our Gibbs free energy calculation of various redox pairs (Fig. S2). A similar conclusion that chelated $\mathrm{Fe}^{3+}$ may increase the redox potential of iron reduction was drawn by Lovley and Phillips (1988) and Thamdrup (2000). The concentration of $\mathrm{Fe}^{3+}$ is generally low in the marine environment due to the low solubility of Fe(III) oxide (e.g., $10^{-8} \mathrm{M}$ with ferrihydrite; Stumm and Morgan (2012)). However, it has been shown that, in the presence of chelators, $\mathrm{Fe}^{3+}$ can be solubilized from the surface of oxide minerals (Lovley 1997). Furthermore, $\mathrm{Fe}^{3+}$ can bind to organic ligands and maintain solubility in seawater (Luther III et al. 1992; Bau et al. 2013). Our calculations suggest that such a process is thermodynamically more favorable if $\mathrm{Fe}^{3+}$ is at the nanomolar level, a reasonable value considering the concentration of organic ligands in seawater (Millero 1998). Future work determining the concentrations of chelators (e.g., organic ligands) is required to test our hypothesis for the co-occurring high $\mathrm{Fe}^{2+}$ and nitrate concentrations in the shallow sediments.

\section{Consumption of $\mathrm{Fe}^{2+}$ through authigenic iron sulfide formation}

Much of the pore fluid $\mathrm{Fe}^{2+}$ is consumed through the precipitation of iron sulfide minerals, a process that is inferred from the abundance of solid-phase sulfur in S-904MC and S$1521 \mathrm{GC}$ (Fig. 4). We detected an order of magnitude more abundant AVS and CRS as compared with previous studies (Lim et al. 2011; Wehrmann et al. 2014). At S-1521GC, AVS 
is most abundant at $3 \mathrm{cmbsf}(0.9 \mathrm{wt} \%$ AVS-Fe or $154 \mu$ mole AVS-S/g sediments) which is 3 to 10 times higher than the content reported by Wehrmann et al. (2014). The highest CRS-Fe abundance from Wehrmann et al. (2014) is ca. $0.25 \mathrm{wt} \%$ whereas, from both S-904MC and S-1521GC, we measured more than $5 \mathrm{wt} \%$ of CRS-Fe. When comparing the abundance of CRS with porewater profiles from S-904MC, we noted that the rapid increase of CRS abundance at the ca. $10 \mathrm{~cm}$ corresponds to the interface between porewater $\mathrm{Fe}^{2+}$ and $\mathrm{LHS}$ (Fig. 4). This correlation may be explained by the rapid formation of pyrite in shallow sediment depths $(<$ $10 \mathrm{cmbsf}$ ). We did not observe any significant changes in CRS abundance or in the $\delta^{34} \mathrm{~S}-\mathrm{CRS}$ across the modern sulfate-methane-transition (SMT) from S-1521GC, though the variable CRS abundance throughout the core makes it difficult to detect potentially small increases in CRS at the SMT. The parallel trend between $\delta^{34} \mathrm{~S}$-AVS and $\Sigma$ HS concentration suggests that AVS uses sulfide and is in equilibrium with the modern pore fluid. On the other hand, the lack of correlation between $\delta^{34}$ S-CRS and $\Sigma$ HS concentration implies that CRS likely integrates the long-term pore fluid sulfide signals produced at different times and rates of sulfate reduction.

\section{$\mathrm{Fe}^{2+}$ fluxes in the surficial sediments of Arctic cold seeps}

Comparison of our flux estimates with those from Svalbard fjords (Wehrmann et al. 2014) and other regions (Dale et al. 2015 and the references therein) shows lower $F_{\text {ox }}$ but comparable $F_{\text {eff }}$ from the investigated cold seeps. $\mathrm{Fe}^{2+}$ can be oxidized in the oxic and suboxic surface sediments by dissolved oxygen and nitrate, respectively, and form nanoparticulate ferrihydrite aggregations that are later scavenged by suspended sediments (Raiswell and Anderson 2005). This re-oxidation process can be quantified by the ratios between $F_{\text {ox }}$ and $F_{\text {eff }}$ (Fig. 3 and Tab. S3). With the exception of anomalous values from cores S-932MC and S-1064MC, on average, $40 \%$ of the $\mathrm{Fe}^{2+}$ that diffuses towards the surface sediments is oxidized. In other words, $\sim 60 \%$ of the $\mathrm{Fe}^{2+}$ produced through iron reduction in the sediment columns can escape the oxidation process in surficial sediments and enter the bottom water (Fig. 3). Such a high proportion may be due to a thin oxic surface layer of sediments facilitating effective escape, though future measurements of dissolved oxygen concentration in the pore fluid are required to verify this. We are aware that our choice of oxygen penetration depth ( $L$ in Eq. (3)) has a profound effect

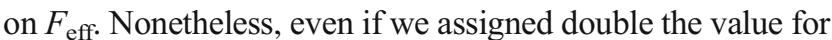
$L(0.2 \mathrm{~cm})$, which reduces $F_{\text {eff }}$ by $53 \%$, our conclusion that more $\mathrm{Fe}^{2+}$ is able to escape from the sediments as compared with those from the Svalbard fjord sites still holds true. Homogenization of surface sediment by benthic fauna, which has been accounted for by the $D_{b}$ coefficients in our flux calculation (Tab. S3), may enhance oxidation and lower the fraction of $\mathrm{Fe}^{2+}$ leaving the sediment column. However, our calculation suggests that such bioturbation can only account for $2-3 \%$ of the $\mathrm{Fe}^{2+}$ oxidation in surface sediments.

\section{Interaction between benthic macrofauna and subsurface geochemistry}

The survival of chemosynthesis-based animals at cold seeps is highly dependent on the cycling and flux of sulfur species (Freytag et al. 2001; Dubilier et al. 2008; Sen et al. 2018a), which in turn also affects the cycling of $\mathrm{Fe}^{2+}$ and vice versa. From the area where core $938 \mathrm{MC}$ was recovered, the seafloor is devoid of any chemosynthesis-based megafauna but colonized by non-seep specialist fauna such as Thenea sponges and anemones (Fig. 5a). There is no detectable $\Sigma H S$ in the top $10 \mathrm{~cm}$ of the sediments as most of the $\Sigma H S$ has been removed by iron sulfide precipitates. Even though no CRS/ AVS abundance data is available at this site, the high S/Al ratio within this sediment interval (Fig. S3 in the Supplementary material) supports this conclusion. The high $\mathrm{Fe}^{2+}$ concentration therefore serves as a "geochemical cap" preventing $\Sigma$ HS from leaking to the bottom ocean, consistent with the low sulfide flux. This in turn allows for colonization by non-seep specialist fauna that does not have adaptations for dealing with sulfide toxicity. In the area where S-904MC was recovered, a dense distribution of Oligobrachia worms containing symbiotic sulfur-oxidizing bacteria in their trunks (Sen et al. 2018b) can be observed (Fig. 5b). These worms likely rely on dissolved sulfide as their primary energy (and ultimately nutrition) source (Sen et al. 2018b) and are able to harvest sulfide deep in the sediments across their half-meterlong tubes. Indeed, $\Sigma$ HS concentration is below the detection limit $(\sim 20 \mu \mathrm{M})$ in the uppermost centimeter from these sediments with $\mathrm{Fe}^{2+}$ concentrations slightly over $100 \mu \mathrm{M}$ (Fig. 5b). Rapid iron reduction and high $\mathrm{Fe}^{2+}$ concentration prevent most of the sulfide from leaking to the bottom ocean at this location as well. Core B-1123BLC represents an extreme case with high $\Sigma H S$ supply and greater than $12 \mathrm{mM} \Sigma \mathrm{HS}$ detected at $15 \mathrm{cmbsf}$ (Fig. 5c). Not only were dense distributions of Oligobrachia worms observed in seafloor images of where this core was recovered from, but additionally, filamentous bacteria (likely sulfur-oxidizing bacteria Lösekann et al. 2008) colonizing the anterior ends of Oligobrachia tubes that extend a few centimeters into the water column were also observed. This colonization results in a fuzzy appearance of the worm tubes as visible in Fig. 5c. The high concentration of $\Sigma$ HS close to the sediment surface and potential leakage to the bottom water accounts for these worm tubes being covered in bacteria, that can use this leaking sulfide as an energy source. These bacteria require oxygen in addition to sulfide for carbon fixation and therefore need to locate themselves at the redox boundary, which is often restricted to the sediment-water 

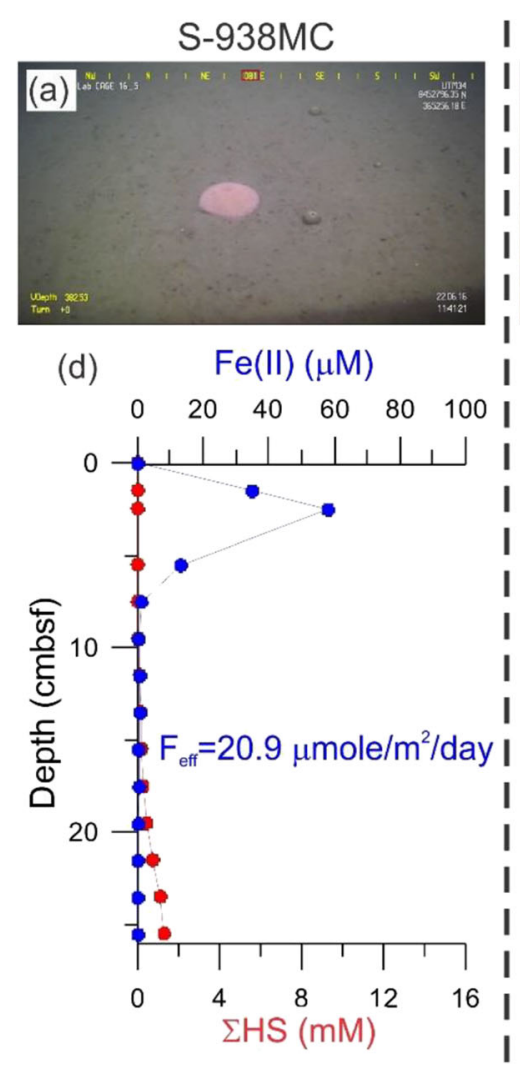

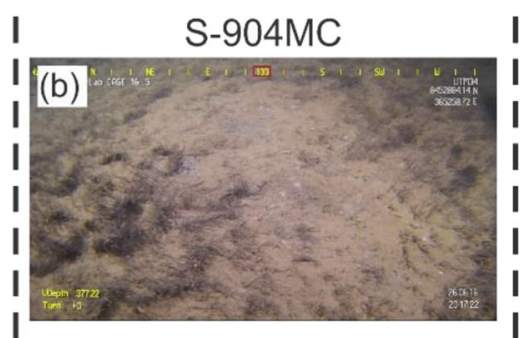

(e)
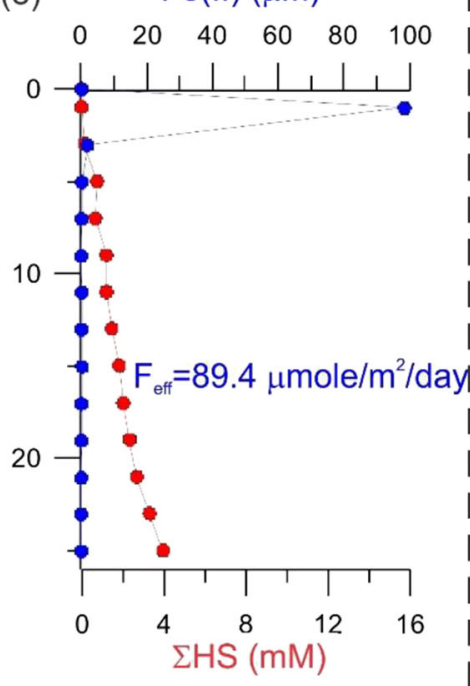
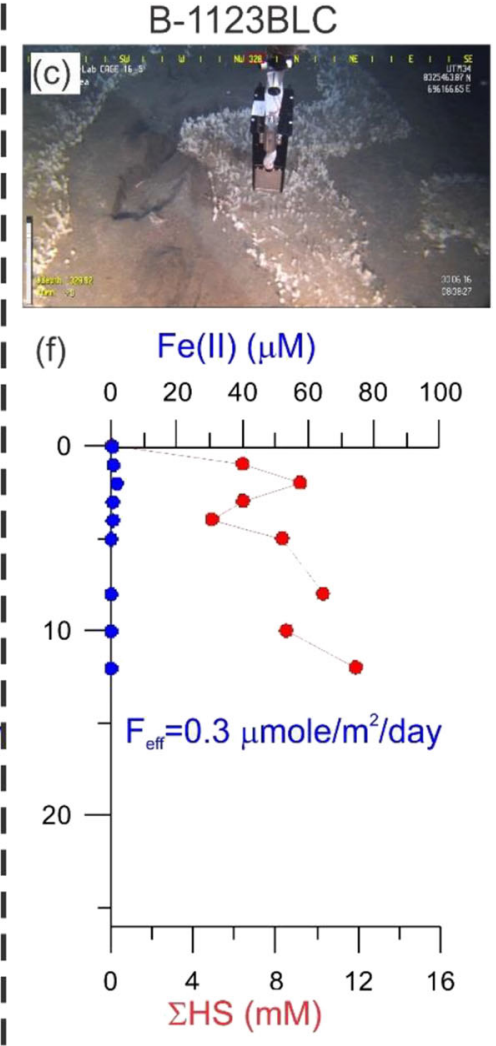

Fig. 5 Comparison of seafloor observations $(\mathbf{a}-\mathbf{c})$ as well as pore fluid $\mathrm{Fe}^{2+}$ and $\Sigma H S$ profiles $(\mathbf{d}-\mathbf{f})$. The joint cycling of iron and sulfur determines the distribution of chemosynthesis-based animals

interface. Leakage of sulfide into the bottom water extends the niche of these bacteria, and the worm tubes provide a settlement surface from which to exploit it.

It is also noteworthy that, immediately adjacent to the bacteria-covered worms, microbial mats were present but not the Oligobrachia worms themselves (the area where imprints of the blade corer are visible in Fig. 5c). We speculate that the sulfide flux in this field of bacterial mats is even higher and that appreciable quantities of hydrogen sulfide may have leaked to the bottom water. Even though Oligobrachia worms are equipped to take up oxygen in hypoxic conditions and further have adaptations against sulfide poisoning, the amount of sulfide reaching the bottom water in this location might be beyond their limits. This could explain their absence from this seafloor patch. Such an explanation is, however, complicated by the fact that the bacteria making up the mat are also aerobic and require access to oxygen. Future studies targeting the two habitats are required to compare the concentrations of hydrogen sulfide in the bottom water.

We also suspect a complicated interaction between nitrogen, sulfur, and iron species occuring in the sediments showing fast sulfide/ $\mathrm{Fe}^{2+}$ turnover (e.g., the sediments from Fig. 5 b and c). Apparent downcore decrease to almost exhaustion in nitrate concentration is only observed from cores S-904MC, S-1029PC, and B-1123BLC with $\Sigma$ HS concentrations higher than $4 \mathrm{mM}$. We propose that the high $\Sigma H S$ concentrations promote the reduction of nitrate in the deeper sediments (> $10 \mathrm{cmbsf}$ ) which is supported by our Gibbs free energy calculation that coupling of denitrification with sulfide oxidation can be equally energetic as the POC-induced nitrification (Fig. S2). It has been shown that the cable bacteria Desulfobulbaceae are able to remotely couple these two redox pairs in marine sediments (Marzocchi et al. 2014). The competition for sulfide between iron sulfide formation and nitrate reduction may also determine the fate of $\mathrm{Fe}^{2+}$ in such sulfiderich sediments. Future work is needed to examine these competing pathways.

\section{Conclusions}

In this study, we present pore fluid and sediment geochemical data to constrain the fate of $\mathrm{Fe}^{2+}$ in four cold seeps along the northern Norwegian margin. We show that DIR alone cannot explain the wide range of iron concentrations and fluxes observed at the investigated sites. The co-appearance of $\mathrm{Fe}^{2+}$ and nitrate in pore fluid in cores from Storfjordrenna and Bjørnøyrenna as well as our thermodynamic calculations leads us to propose that aqueous $\mathrm{Fe}^{3+}$ reduction plays a significant role in producing $\mathrm{Fe}^{2+}$. A significant fraction of the $\mathrm{Fe}^{2+}$ is precipitated as iron sulfide minerals, as supported by the high abundance of AVS and CRS. We demonstrate that, 
despite the lower $\mathrm{Fe}^{2+}$ fluxes towards the oxic sediment layer into the bottom water as compared with those estimated in Svalbard fjord sediments, a larger proportion of $\mathrm{Fe}^{2+}$ is able to escape the sediments from our study areas. This can be attributed to a potentially thin oxic layer in sediments of our sites. The comparison between seafloor macrofauna assemblage and subsurface geochemical profiles reveals the interaction and geochemical control on the distribution of chemosynthesis-based macrofauna.

Acknowledgments We would like to acknowledge the captains and crews onboard R/V Helmer Hanssen for cruises in HH13, CAGE15-2, CAGE15-6, and CAGE16-5. We are grateful for the chief scientists, Dr. Matthias Forwick (HH13), Dr. Giuliana Panieri (CAGE15-2), Dr. Jurgen Mienert (CAGE15-6), and Dr. Michael Carroll (CAGE16-5). We appreciate the team from Woods Hole Oceanographic Institution (WHOI) MISO (Multidisciplinary Instrumentation in Support of Oceanography) (Dr. Daniel Fornari and Gregory Kurras) operating the TowCam deep-sea imaging system and the ROV team (Prof. Dr. Martin Ludvigsen, Frode Volden, Stein Nornes, and Pedro de la Torre) from the Norwegian Centre for Autonomous Marine Operations and Systems (AMOS) for their assistance in sample collection. We would also like to thank Mrs. Haoyi Yao for her assistance in porewater sampling and analyses. The constructive and insightful comments from Dr. Susann Henkel and two anonymous reviewers greatly improve the quality of this manuscript. The handling of the paper by the Editor-in-Chief of Geo-Marine Letters Dr. Gabriele Uenzelmann-Neben is also much appreciated.

Funding information Open Access funding provided by UiT The Arctic University of Norway. This work was supported by the Research Council of Norway through its Centres of Excellence funding scheme (project number 223259) and NORCRUST (project number 255150).

Open Access This article is licensed under a Creative Commons Attribution 4.0 International License, which permits use, sharing, adaptation, distribution and reproduction in any medium or format, as long as you give appropriate credit to the original author(s) and the source, provide a link to the Creative Commons licence, and indicate if changes were made. The images or other third party material in this article are included in the article's Creative Commons licence, unless indicated otherwise in a credit line to the material. If material is not included in the article's Creative Commons licence and your intended use is not permitted by statutory regulation or exceeds the permitted use, you will need to obtain permission directly from the copyright holder. To view a copy of this licence, visit http://creativecommons.org/licenses/by/4.0/.

\section{References}

Aller RC (1980) Diagenetic processes near the sediment-water interface of Long Island sound. I.: Decomposition and nutrient element geochemistry (S, N, P). Adv Geophys, Elsevier 22:237-350

Aller RC (1982) The effects of macrobenthos on chemical properties of marine sediment and overlying water. In: Animal-sediment relations. Springer, Berlin, pp 53-102

Aller RC (1994) Bioturbation and remineralization of sedimentary organic matter: effects of redox oscillation. Chem Geol 114(3-4):331-345

Anderson LG, Jones EP, Lindegren R, Rudels B, Sehlstedt P-I (1988) Nutrient regeneration in cold, high salinity bottom water of the Arctic shelves. Cont Shelf Res 8(12):1345-1355
Andreassen K, Hubbard A, Winsborrow M, Patton H, Vadakkepuliyambatta S, Plaza-Faverola A, Gudlaugsson E, Serov P, Deryabin A, Mattingsdal R (2017) Massive blow-out craters formed by hydrate-controlled methane expulsion from the Arctic seafloor. Science 356(6341):948-953

Bau M, Tepe N, Mohwinkel D (2013) Siderophore-promoted transfer of rare earth elements and iron from volcanic ash into glacial meltwater, river and ocean water. Earth Planet Sci Lett 364:30-36

Boudreau BP, Scott MR, (1978) A model for the diffusion-controlled growth of deep-sea manganese nodules. Am J Sci 278:903-929

Boetius A, Wenzhofer F (2013) Seafloor oxygen consumption fuelled by methane from cold seeps. Nat Geosci 6(9):725-734

Boudreau BP (1997) Diagenetic models and their implementation: modeling transport and reactions in aquatic sediments. Springer, Berlin

Boyd PW, Watson AJ, Law CS, Abraham ER, Trull T, Murdoch R, Bakker DC, Bowie AR, Buesseler K, Chang H (2000) A mesoscale phytoplankton bloom in the polar Southern Ocean stimulated by iron fertilization. Nature 407(6805):695-702

Canfield DE, Raiswell R, Westrich JT, Reaves CM, Berner RA (1986) The use of chromium reduction in the analysis of reduced inorganic sulfur in sediments and shales. Chem Geol 54(1):149-155

Canfield DE, Thamdrup B, Hansen JW (1993) The anaerobic degradation of organic matter in Danish coastal sediments- iron reduction, manganese reduction, and sulfate reduction. Geochim Cosmochim Acta 57(16):3867-3883

Chand S, Rise L, Bellec V, Dolan M, Bøe R, Thorsnes T, Buhl-Mortensen P (2008) Active venting system offshore Northern Norway. EOS Trans Am Geophys Union 89(29):261-262

Dale AW, Nickelsen L, Scholz F, Hensen C, Oschlies A, Wallmann K (2015) A revised global estimate of dissolved iron fluxes from marine sediments. Glob Biogeochem Cycles 29(5):691-707

Dubilier N, Bergin C, Lott C (2008) Symbiotic diversity in marine animals: the art of harnessing chemosynthesis. Nat Rev Microbiol 6(10):725-740

Egger M, Kraal P, Jilbert T, Sulu-Gambari F, Sapart CJ, Röckmann T, Slomp CP (2016) Anaerobic oxidation of methane alters sediment records of sulfur, iron and phosphorus in the Black Sea. Biogeosciences 13(18):5333

Fischer D, Sahling H, Nöthen K, Bohrmann G, Zabel M, Kasten S (2012) Interaction between hydrocarbon seepage, chemosynthetic communities, and bottom water redox at cold seeps of the Makran accretionary prism: insights from habitat-specific pore water sampling and modeling. Biogeosciences 9(6):2013-2031

Fossing H, Jørgensen BB (1989) Measurement of bacterial sulfate reduction in sediments: evaluation of a single-step chromium reduction method. Biogeochemistry 8(3):205-222

Freytag JK, Girguis PR, Bergquist DC, Andras JP, Childress JJ, Fisher CR (2001) A paradox resolved: sulfide acquisition by roots of seep tubeworms sustains net chemoautotrophy. Proc Natl Acad Sci 98(23):13408-13413

Froelich PN, Klinkhammer GP, Bender ML, Luedtke NA, Heath GR, Cullen D, Dauphin P, Hammond D, Hartman B, Maynard V (1979) Early oxidation of organic matter in pelagic sediments of the eastern equatorial Atlantic: suboxic diagenesis. Geochim Cosmochim Acta 43(7):1075-1090

Hong W-L, Torres ME, Carroll J, Crémière A, Panieri G, Yao H, Serov P (2017) Seepage from an arctic shallow marine gas hydrate reservoir is insensitive to momentary ocean warming. Nat Commun 8:15745

Larsen O, Postma D (2001) Kinetics of reductive bulk dissolution of lepidocrocite, ferrihydrite, and goethite. Geochim Cosmochim Acta 65(9):1367-1379

Lenstra W, Hermans M, Séguret MJ, Witbaard R, Behrends T, Dijkstra N, van Helmond NA, Kraal P, Laan P, Rijkenberg MJ (2019) The shelfto-basin iron shuttle in the Black Sea revisited. Chem Geol 511:314 341 
Lim YC, Lin S, Yang TF, Chen YG, Liu CS (2011) Variations of methane induced pyrite formation in the accretionary wedge sediments offshore southwestern Taiwan. Mar Pet Geol 28(10):1829-1837

Long D, Lammers S, Linke P (1998) Possible hydrate mounds within large sea-floor craters in the Barents Sea. Geol Soc Lond, Spec Publ 137(1):223-237

Lösekann T, Robador A, Niemann H, Knittel K, Boetius A, Dubilier N (2008) Endosymbioses between bacteria and deep-sea siboglinid tubeworms from an Arctic cold seep (Haakon Mosby mud volcano, Barents Sea). Environ Microbiol 10(12):3237-3254

Lovley DR (1997) Microbial Fe (III) reduction in subsurface environments. FEMS Microbiol Rev 20(3-4):305-313

Lovley DR, Phillips EJ (1988) Novel mode of microbial energy metabolism: organic carbon oxidation coupled to dissimilatory reduction of iron or manganese. Appl Environ Microbiol 54(6):1472-1480

Lucchi RG, Pedrosa MT, Camerlenghi A, Urgeles R, De Mol B, Rebesco M (2012) Recent submarine landslides on the continental slope of Storfjorden and Kveithola trough-mouth fans (north West Barents Sea). In: Submarine mass movements and their consequences. Springer, Berlin, pp 735-745

Luther GW III, Kostka JE, Church TM, Sulzberger B, Stumm W (1992) Seasonal iron cycling in the salt-marsh sedimentary environment: the importance of ligand complexes with $\mathrm{Fe}$ (II) and $\mathrm{Fe}$ (III) in the dissolution of Fe (III) minerals and pyrite, respectively. Mar Chem 40(1-2):81-103

Lyons TW, Severmann S (2006) A critical look at iron paleoredox proxies: new insights from modern euxinic marine basins. Geochim Cosmochim Acta 70(23):5698-5722

Marzocchi U, Trojan D, Larsen S, Meyer RL, Revsbech NP, Schramm A, Nielsen LP, Risgaard-Petersen N (2014) Electric coupling between distant nitrate reduction and sulfide oxidation in marine sediment. ISME J 8(8):1682-1690

Middelburg JJ, Soetaert K, Herman PM (1997) Empirical relationships for use in global diagenetic models. Deep-Sea Res I Oceanogr Res Pap 44(2):327-344

Millero FJ (1998) Solubility of Fe (III) in seawater. Earth Planet Sci Lett 154(1-4):323-329

Millero FJ (2001) The physical chemistry of natural waters/by Frank J. Millero. Wiley-Interscience series in geochemistry

Millero FJ, Sotolongo S, Izaguirre M (1987) The oxidation kinetics of Fe (II) in seawater. Geochim Cosmochim Acta 51(4):793-801

Niewöhner C, Hensen C, Kasten S, Zabel M, Schulz HD (1998) Deep sulfate reduction completely mediated by anaerobic methane oxidation in sediments of the upwelling area off Namibia. Geochim Cosmochim Acta 62(3):455-464

Ofstad S, Meilland J, Zamelczyk K, Chierici M, Fransson A, Gründger F, Rasmussen TL (2020) Development, productivity, and seasonality of living planktonic foraminiferal faunas and Limacina helicina in an Area of intense methane seepage in the Barents Sea. J Geophys Res Biogeosci 125(2):e2019JG005387

Patton H, Andreassen K, Bjarnadóttir LR, Dowdeswell JA, Winsborrow M, Noormets R, Polyak L, Auriac A, Hubbard A (2015) Geophysical constraints on the dynamics and retreat of the Barents Sea ice sheet as a paleobenchmark for models of marine ice sheet deglaciation. Rev Geophys 53(4):1051-1098

Plassen L, Vorren TO (2003) Fluid flow features in fjord-fill deposits, Ullsfjorden, North Norway. Nor Geol Tidsskr 83(1):37-42

Raiswell R, Anderson T (2005) Reactive iron enrichment in sediments deposited beneath euxinic bottom waters: constraints on supply by shelf recycling. Geol Soc Lond, Spec Publ 248(1):179-194

Raiswell R, Canfield DE (1998) Sources of iron for pyrite formation in marine sediments. Am J Sci 298(3):219-245

Raiswell R, Canfield DE (2012) The iron biogeochemical cycle past and present. Geochem Perspect 1(1):1-2
Reimers CE, Ruttenberg KC, Canfield DE, Christiansen MB, Martin JB (1996) Porewater $\mathrm{pH}$ and authigenic phases formed in the uppermost sediments of the Santa Barbara Basin. Geochim Cosmochim Acta 60(21):4037-4057

Rickard D, Luther GW III (2007) Chemistry of iron sulfides. Chem Rev 107(2):514-562

Riedinger N, Pfeifer K, Kasten S, Garming JFL, Vogt C, Hensen C (2004) Iron diagenesis within and below the zone of anaerobic oxidation of methane. Geochim Cosmochim Acta 68(11):A341-A341

Riedinger N, Pfeifer K, Kasten S, Garming JFL, Vogt C, Hensen C (2005) Diagenetic alteration of magnetic signals by anaerobic oxidation of methane related to a change in sedimentation rate. Geochim Cosmochim Acta 69(16):4117-4126

Riedinger N, Brunner B, Krastel S, Arnold GL, Wehrmann LM, Formolo MJ, Beck A, Bates SM, Henkel S, Kasten S, Lyons TW (2017) Sulfur cycling in an iron oxide-dominated, dynamic marine depositional system: the argentine continental margin. Front Earth Sci $5(33)$

Sauer S, Knies J, Lepland A, Chand S, Eichinger F, Schubert CJ (2015) Hydrocarbon sources of cold seeps off the Vesterålen coast, northern Norway. Chem Geol 417:371-382

Sauer S, Hong WL, Knies J, Lepland A, Forwick M, Klug M, Eichinger F, Baranwal S, Crémière A, Chand S (2016) Sources and turnover of organic carbon and methane in fjord and shelf sediments off northern Norway. Geochem Geophys Geosyst 17(10):4011-4031

Schulz HD, Dahmke A, Schinzel U, Wallmann K, Zabel M (1994) Early diagenetic processes, fluxes, and reaction-rates in sediments of the south-Atlantic. Geochim Cosmochim Acta 58(9):2041-2060

Seeberg-Elverfeldt J, Schlüter M, Feseker T, Kölling M (2005) Rhizon sampling of porewaters near the sediment-water interface of aquatic systems. Limnol Oceanogr Methods 3(8):361-371

Sen A, Åström EKL, Hong WL, Portnov A, Waage M, Serov P, Carroll ML, Carroll J (2018a) Geophysical and geochemical controls on the megafaunal community of a high Arctic cold seep. Biogeosciences 15(14):4533-4559

Sen A, Duperron S, Hourdez S, Piquet B, Léger N, Gebruk A, Le Port AS, Svenning MM, Andersen AC (2018b) Cryptic frenulates are the dominant chemosymbiotrophic fauna at Arctic and high latitude Atlantic cold seeps. PLoS One 13(12):e0209273

Severmann S, McManus J, Berelson WM, Hammond DE (2010) The continental shelf benthic iron flux and its isotope composition. Geochim Cosmochim Acta 74(14):3984-4004

Straub KL, Benz M, Schink B (2001) Iron metabolism in anoxic environments at near neutral pH. FEMS Microbiol Ecol 34(3):181-186

Stumm W, Morgan JJ (2012) Aquatic chemistry: chemical equilibria and rates in natural waters. Wiley, Hoboken

Tagliabue A, Bowie AR, Boyd PW, Buck KN, Johnson KS, Saito MA (2017) The integral role of iron in ocean biogeochemistry. Nature 543:51

Thamdrup B (2000) Bacterial manganese and iron reduction in aquatic sediments. Adv Microb Ecol 16(16):41-84

Traister GL, Schilt AA (1976) Water-soluble sulfonated chromogenic reagents of the ferroin type and determination of iron and copper in water, blood serum, and beer with the tetraammonium salt of 2, 4bis (5, 6-diphenyl-1, 2, 4-triazin-3-yl) pyridinetetrasulfonic acid. Anal Chem 48(8):1216-1220

Wehrmann LM, Formolo MJ, Owens JD, Raiswell R, Ferdelman TG, Riedinger N, Lyons TW (2014) Iron and manganese speciation and cycling in glacially influenced high-latitude fjord sediments (West Spitsbergen, Svalbard): evidence for a benthic recyclingtransport mechanism. Geochim Cosmochim Acta 141:628-655

Publisher's note Springer Nature remains neutral with regard to jurisdictional claims in published maps and institutional affiliations. 